\title{
"IF MY MOTHER WERE STILL ALIVE, I AND YOU WOULD DEFINITELY GET DIVORCED": A CASE STUDY OF A VIETNAMESE WOMAN'S REFUSING IN INTERACTION
}

\author{
Nguyen Trong $\mathrm{Du}^{*}$ \\ School of Foreign Languages, Thai Nguyen University, Quyet Thang, Thai Nguyen, Vietnam
}

Received 16 August 2018

Revised 25 January 2019; Accepted 29 January 2019

\begin{abstract}
This paper presents the major findings from a recent study conducted to explore how a Vietnamese woman refuses a high-stakes advice or request in everyday conversations. Data used in this study are conversations excerpted from a TV series entitled Nhũng công dân tập thể (lit. the citizens living in the same apartment building). The analytical tool is a combination of Conversation Analysis (Hutchby \& Wooffitt, 1998, 2008; Sacks, 1992a, 1992b) and Multimodal Interactional Analysis (Norris, 2004, 2009). The results show that (1) Vietnamese refusing is often performed concurrently by different modes of communication and language is only one of them; (2) refusing a high-stakes advice or request often takes a long time to negotiate in a conversation and through a series of conversations; and (3) Vietnamese women's responsibility to obey their parents, a Confucian teaching, still has its role in contemporary Vietnamese society.
\end{abstract}

Keywords: Vietnamese refusing, refusal, interactional data, conversation analysis, multimodal interactional analysis

\section{Introduction}

In the past 40 years, research on refusing has witnessed a significant growth in different ways. First, refusing has been explored in different languages and cultures such as English, Chinese, Spanish, Persian, Arabic, and Japanese ${ }^{1}$. Second, refusing together with its related phenomena such as face, facework, and politeness have been explored from the point of view of different disciplines including anthropology, sociolinguistics, linguistic ethnography, psycholinguistics, among others

\footnotetext{
Tel.: 84-912452262

Email: nguyentrongdu.sfl@tnu.edu.vn

1 For a relatively full reference of speech act types and languages explored in pragmatics see the website of the Center for Advanced Research on Language Acquisition (CARLA), University of Minnesota, available at http://www.carla.umn.edu/speechacts/ bibliography/topics/focusarea.html
}

(Sbisà \& Turner, 2013). Third, refusing has been explored in different domains including intra-cultural, cross-cultural and inter-cultural studies (see Nguyễn Trọng Du (2016) for a thorough review of studies on refusing).

Despite this growth, the research theme is underexplored in relation to the Vietnamese language and culture. There are a few articles on Ngôn ngũu (Language) and Ngôn ngũ và Đò̀i sống (Language \& Life) - two most famous journals of The Vietnamese language (e.g. Lưu Quý Khương \& Trần Thị Phương Thảo, 2008; Nguyễn Phương Chi, 1997, 2004a; Trần Chi Mai, 2005a, 2005b, 2005d; Vũ Tiến Dũng \& Nguyễn Thị Thu Thuỷ, 2009). However, these articles are either rather narrow in their scope of research or just the publications of some of the findings from a bigger study such as an MA or a $\mathrm{PhD}$ dissertation; therefore, in the following paragraphs, the author focuses 
on reviewing these dissertations.

There are two MA theses (Nguyễn Thị Minh Phương, 2006; Phan Thị Vân Quyên, 2001) and two $\mathrm{PhD}$ dissertations (Nguyễn Phương Chi, 2004; Trần Chi Mai, 2005c). These theses share the following common features: (1) They are, for a large part, crosscultural studies so they generally draw on the etic perspective (Pike, 1954) to explain the strategies used by language users; (2) they focus more on exploring linguistic forms than on explicating the underlying cultural factors; (3) they mainly draw on quantitative methods of data collection and analysis; and (4) they do not explore refusals in interaction.

First, all the four theses are cross-cultural studies which aim at comparing refusing strategies used by Vietnamese people and those by native speakers of English, and thus the authors generally draw on the etic ${ }^{2}$ perspective to draw conclusions. This perspective typically generalises the findings to the whole population of the culture as this generalisation allows them to compare the norms of using language in one culture with those in another culture. For example, Nguyễn Thị Minh Phương (2006) stated Vietnamese native speakers were more careful than Australians about the way they refused and that Australians were more direct than the Vietnamese. Besides, both Phan Thị Vân Quyên's (2001) and Nguyễn Phương Chi's (2004b) findings showed that Vietnamese people use indirect strategies more frequently than their Anglicist counterparts, with $84.97 \%$ and $58.48 \%$ respectively in Phan Thị Vân Quyên's study and $76.1 \%$ and $64.4 \%$ in Nguyễn Phương Chi's. While these findings

2 See Triandis (1994, p. 67), Matsumoto and Juang (2004, p. 67) for further conceptualizations of emics and etics. are valuable for making general comparisons between the two cultures in question, the conventionalised and 'conservative' norms may not necessarily provide adequate explanation for the varied practices in real life (Mills \& Kádár, 2011). Indeed, cultures should not be understood as homogeneous but as contested in nature because within each culture people may have different views on what constitutes norms and values.

Second, all the four studies on Vietnamese refusals also place more emphasis on pragmalinguistics which is "the study of the more linguistic end of pragmatics" (Leech, 1983 , p. 11) than on sociopragmatics which is the study focusing more on cultural aspects than linguistic ones. As such, only the linguistic formula (Beebe, Takahashi, \& UlissWeltz, 1990) are explored and so language seems to be the only means of conveying the message of a refusal. Although this focus on linguistic resources is important in crosscultural studies, the socio-cultural factors underpinning the use of semantic formulas are also worth examining. Thomas (1983), when dealing with students' pragmatic failures in cross-cultural communication, takes this point even further arguing that pragmalinguistic failure can be easier to fix than sociopragmatic failure. She claimed that this is because the linguistic conventionalised forms "can be taught quite straightforwardly as "part of the grammar' whereas sociopragmatic failure "involves the student's system of beliefs as much as his/her knowledge of the language" (p. 91).

The third feature, and also the consequence of the other two features, is the frequent use of Discourse Completion Tests (henceforth DCTs) as a method of eliciting data (e.g. Nguyễn Thị Minh Phương, 2006; 
Phan Thị Vân Quyên, 2001; Trần Chi Mai, 2005c). DCTs ${ }^{3}$ were originally developed by Blum-Kulka (1982) during her comparison of speech act realizations between native and non-native Hebrew speakers. In the DCTs, participants are required to fill in the blanks indicating what they think they would say in a given situation. Response data are normally coded into semantic formulas and analysed by quantitative tools. Although DCTs help researchers obtain a great deal of comparable data in a short period of time (A1Eryani, 2007; Allami \& Naeimi, 2011; FélixBrasdefer, 2006, 2008; Kwon, 2004), they reveal a number of drawbacks (see Beebe and Cummings, 1996, p. 80). In real life people may not refuse in some of the situations given in the DCTs. Phan Thị Vân Quyên (2001), for example, admits that some informants in her study did not provide refusals to the request given in the DCTs because they said they would not refuse such a request. Moreover, they reported that if they were to refuse then a number of turns and negotiations would be likely to occur rather than just the one-toone response provided in the DCTs. Thus, by asking participants to produce oral or written refusals, researchers using DCTs may unintentionally 'force' participants to refuse in situations in which they may not actually do so in real life.

Finally, all the studies do not explore refusing in interaction and thus they cannot touch upon non-linguistic modes of communication. The term refusing in interaction is creatively used in this paper as one type of the more general term talk-in-

\footnotetext{
DCTs are originally "written questionnaires including a number of brief situational descriptions, followed by a short dialog with an empty slot for the speech act under study" (Kasper \& Dahl, 1991, p. 221) (see Pavaresh \& Tavakoli, 2009 for other types of DCTs).
}

interaction which has been well established in conversation analysis. As Hutchby and Wooffitt (2008, p. 11) claim, conversation analysis is the study of talk produced in everyday situations of human interaction, and thus this talk is often referred to as talk-ininteraction (the term is written with hyphens). In the literature of conversation analysis, there has been a number of books and journal articles using this term with or without a replacement of the word 'talk', such as Impoliteness in Interaction (2008) by Derek Bousfield, or Talk-in-interaction: multilingual perspectives (2009) edited by Hanh Thi Nguyen and Gabriele Kasper. It has been widely evidenced that in interaction, people often concurrently use different tools to convey their intended meaning and language is only one of the tools. Norris (2004, p. 2) states that language is only one mode of communication "which may or may not take a central role at any given moment in an interaction" and thus exploring only language will limit "our understanding of the complexity of interaction".

Accordingly, this paper presents the major findings of a case study that explores the speech act of refusing performed by a Vietnamese woman from an interactional perspective. As such, it attempts to answer two main questions:

1. How are different modes of communication used by the Vietnamese woman to refuse a high-stakes advice or request?

2. How is it negotiated in one conversation and through a series of conversations?

The findings obtained from answering these two questions help to answer the third question - the conclusive one:

3. How does the Vietnamese woman's responsibility to obey her parents constrain 
and condition her refusing?

It should be noted here that in this paper the author deliberately uses the term 'refusing' instead of 'refusal' for several reasons. First, refusing implies the whole process of making one or more refusals, and it can cover the actions (verbal or non-verbal) that do not seem to constitute a refusal (according to traditional classification) but in fact have the function of a refusal or at least of a signal to refuse. In other words, it refers to utterances or behavior that may not be classified by linguists as refusals basing on the literal meaning. For example, the utterance "Yes, OK, let me ask my wife if we have already had any plan with our saving" used to respond to a request of borrowing money may not be classified as a refusal in terms of semantics, but it is regarded by many Vietnamese people as an indirect refusal (Nguyễn Trọng Du, 2016). Second, during the process of negotiation, refusing can be changed; that is, a person may want to refuse at first, but then decide to accept or vice versa. This fact is not at all rare in real life, especially when the refusal is made in response to a high-stakes advice or request, the one that may have a great impact on the refuser's life. Third, refusing is explored not only from the speaker's intention but also from the hearer's interpretation. This is quite interesting in that sometimes the refuser does not refuse directly; s/he says something very indirect and lets the hearer figure out the message of a refusal. Fourth, refusing is not only explored from the speaker's words but also from his or her actual non-verbal actions that he or she performs later. In other words, $\mathrm{s}$ /he may not refuse in words but does not do things as requested or invited by his or her interlocutor. Finally, exploring refusing as a process can better reveal the full vivid picture of the sociocultural affordances underlying it.

Another term that needs clarifying is "high-stakes" which is used in this paper as a pre-modifier of the two nouns "advice" and "request". It refers to something very important, something that may cause a big change to addressees. Thus, a high-stakes advice is an advice that may have a big impact on the person who is advised. For example, to advise a woman to get divorced from her husband can be regarded as a high-stakes one because it may lead to a big change of her life.

\section{Data and the analytical tools}

\subsection{Data}

The data used in this paper are conversations excerpted from a movie entitled Nhũng công dân tập thể (lit. the citizens living in the same apartment building) produced in 2011. This 36-episode TV series, which can be downloaded free from YouTube, is about everyday matters occurring in a small community of people who are living in the same apartment building in Hanoi. The reason to choose this movie is that it depicts casual and mundane encounters between family members or between neighbours that take place in their daily life. Many of these encounters elaborate problems and conflicts such as getting divorced, quarrelling between neighbours, and the issues of inheritance where refusing is very likely to occur. It can be said that this movie mirrors the real contemporary society of Hanoi - the capital city of Vietnam - in the first decade of the $21^{\text {st }}$ century.

The conversations taken for analysis in this paper are about a story of getting divorced. The main character is Dương 
- a well-educated woman - who has just finished her $\mathrm{PhD}$ course in sociology. She is married to Kinh who is a car-driving instructor at a driving school and they have a pre-school son. Since Kinh comes from the countryside, he has to stay with his wife's family that consists of her mother and her younger brother (in Vietnam it is quite rare for a husband to stay with his wife's family). Totally, there are 5 people living in an apartment unit including Dương, her husband Kỉnh, her son Tít, her mother Mai, and her younger brother Hoàng. Her mother is a retired schoolteacher who got divorced from her father a long time ago. Her father left them and has married another lady, but her mother just stays as a single mum.

The conversations in this paper take place after Dương has decided to get divorced from her husband since she discovered that he is having a love affair with another woman, one of his driving learners at the driving school. Knowing about this problem, her mother tries to advise and request her to cancel her decision to get divorced drawing on the reason that a divorced woman will have a difficult life (the mother herself has been bearing the consequences of being a single mum). There are five conversations (or five scenes) between her and the mother and other family members. For the scope of this paper, however, the author would select two of them for analysis: the first and the last. The first is the dialogue between Dương and her mother, and the last is the dialogue between her and her husband. The other three conversations are between her and her mother (the second), between her and other adult members in her family (the third) and between her and the ghost of her mother (the fourth, after the mother dies from an accident).

\subsection{Analytical tools}

Taking the stance of a constructionist view which is influenced by Garfinkel's (1967) ethnomethodology, Goffman's (1983) interaction order and Gumperz's (1982) interactional sociolinguistics, the author treats refusing as both a process and procduct rather than just as a product; that is, how refusing is negotiated and performed through a series of conversations between persons involved rather than just what they actually say and do to refuse. Accordingly, the study relied on a combination of Conversation Analysis (CA) and Multimodal Interactional Analysis (MIA) as analytical tools which the author believes to be specifically helpful for the analysis of the interactional data.

2.2.1. A justification for the use of $C A$ to analyze movie data

The present study drew on CA (Hutchby \& Wooffitt, 2008; Sacks, 1992a, 1992b) as an informed-tool of analysis, with informed in the sense that CA is not applied with its full feature because the movie conversations are not considered naturally-occuring data. It has been accepted that what the persons in a TV series or a movie say and do will not be treated as naturally-occuring data; they should only be regarded as reflection of natural talks in real life. In using CA to analyze scripted data, the author is aware that he had 'violated' the principle of $\mathrm{CA}$ which requires the study of naturally-occuring conversations. However, he was not doing this without theoretical and methodological bases. In fact, he was always aware that filmic conversations, although having almost all features of a natural interaction, are only the reflection of what the film makers including the screenwriter, the director, actors and actresses perceive to be the 
case in real-life communication, as well as the reflection of what they think the viewers would think to be the case in real-life communication. Accordingly, he was aware of what kind of claims he can or cannot make based on this kind of data. There have been a number of studies (e.g. Gilmore, 2004; Holmes, 1998; Nguyen Thi Hanh \& Ishitobi, 2012; Nguyen Thi Thuy Minh, 2011; Scotton \& Bernsten, 1988; Uso-Juan, 2008; Wong, 2002) showing how constructed dialogues deviate from what actually happens in real life.

However, there have also been several authors (e.g. Bowles, 2009; Herman, 1998; Ivanchenko, 2007) who applied CA on analysing literary works and they argued that CA can be usefully applied to constructed conversations if attention is sufficiently paid to what can be concluded from the findings. In another article on the contribution of CA to the study of literary dialogue, Bowles (2011, p. 165) quoted Keith Richards' words (through personal communication) that "it may be legitimate to claim that talk produced by the writer is 'naturally-occurring' data and that this kind of 'writer-constructed' dialogue may be a legitimate object of CA as long as the analysis is aware of its 'constructedness' and takes it into account".

\subsubsection{A justification for the use of MIA}

MIA (Norris, 2004) was also used for the analysis of the data. Influenced by mediated discourse analysis (Scollon, 2001), MIA sees that every action is mediated (Norris, 2004) either by language or any other modes of communication, or by a combination of those modes. Thus, refusing as an action is mediated by a number of mediational tools among which language is only one. The tools may be utilized one at a time, but very often several tools are used concurrently, which makes a complexity of modes (Norris, 2004).

The use of MIA does not mean that CA cannot be used to analyse the non-linguistic actions such as gesture, gaze, as well as the role of the material objects. There have been a good number of studies analysing those communication modes using CA (e.g. C. Goodwin, 1981; 1994, M. H. Goodwin, 1990 etc). However, CA approach to multimodality is different from MIA in two fundamental areas (Mortensen, 2013). First, the latter often analyses each semiotic mode in its own right whereas the former does not describe each mode independently but as an interplay between various semiotic fields. Second, although MIA assumes that every mode is relevant and affects the ongoing interaction, it does not adopt an emic approach as CA does. In other words, it does not necessarily include a social (i.e., the participants' understanding of prior turn and taking next turn) interactional perspective in the analysis. As such, whereas MIA assumes that every semiotic mode is relevant, CA assumes that "everything might be relevant, but is not necessarily made relevant by the participants." (Mortensen, 2013, p.2).

Since the author draws on movie conversations, he needs to analyse both how the participants (i.e., the actors and actresses) make relevant the communication modes at hand (more exactly, how the film makers direct them to make use of those modes) and how the film makers make relevant other modes independent from the job of the actors and actresses. In other words, since he analysed conversations from a TV series, which are scripted, not only the modes made relevant by the participants but also those that were not would be analysed.

During an interaction, there are moments 
when language takes the main role and becomes the embodied mode of interaction whereas other modes such as gaze, gesture, or material objects become disembodied (Norris, 2004). There are other moments when language plays a minor role in conveying the message and thus becomes disembodied whereas another mode can become prominent. The analysis of data in this study reveals how different modes of communication have their own roles in expressing the message of a refusal.

\section{Analysis and discussion}

The following conversations were transcribed using transcript conventions invented by Gail Jefferson (2004). The first line is the Vietnamese version, the second is the word by word gloss and the third line is the translation. For the sake of reader-friendliness, the translation lines are all in bold.

3.1. The first conversation: Episode 22 (30’04-33'10)

\subsubsection{A brief description of the first part} of the conversation

The conversation, part of which is transcribed below for analysis, takes place between Dương and her mother, Mai, in Dương's bedroom. They are both sitting on Dương's bed; Mai is holding a bracelet and Dương is holding some photos. In front of them is the box used to store the bracelet, photos, and other objects. All of the things are possesions Mai had had before she divorced her husband and which she has been keeping as souvenirs that remind her of the good old time before the divorce.

Knowing that Dương has decided to divorce her husband, Mai is trying to advise her to cancel her decision. At the beginning of the conversation, Mai tells a story about the difficult time in the past when she and the whole family had to live a hard life before she got divorced from her husband (i.e., Dương's father). She starts the story by saying that every marriage is the result of love, and that because of having love, she and her husband had had a good time together. What she implies is that if a husband and a wife love each other, together they can overcome all difficulties they may encounter in their life. Therefore, although the whole family were so poor that they did not have enough food to eat and clothes to wear, she and her husband still loved each other, and there was a lot of laughter in the family. Dương listens to the story attentively. She shows her display of recipiency (Heath, 1984) by gazing at Mai in a sympathetic manner and then starting to cry. At the time being recounted, Dương was a small child, but old enough to remember what happened. Thus, she contributes to her mother's story by mentioning the birth of her younger brother, Hoàng. By doing so, she indicates her shared knowledge and mutual understanding with her mother. As such, both of them display their mutual understanding, or harmony, in talk.

Mai continues her story by saying that as the result of the increasing hardship, her husband felt bored and went out more often, and he ended up having a love affair with another woman. The consequence of this affair is that she decided to get divorced from him because, as she narrates, she has her own self-esteem. This divorce made her life as a single mum even more difficult, and she wishes she would not have been so intolerant to her husband. By telling this story, she wants to advise Dương that if Dương tries to get divorced, she will encounter similar difficulty; and the conversation continues as transcribed below. 


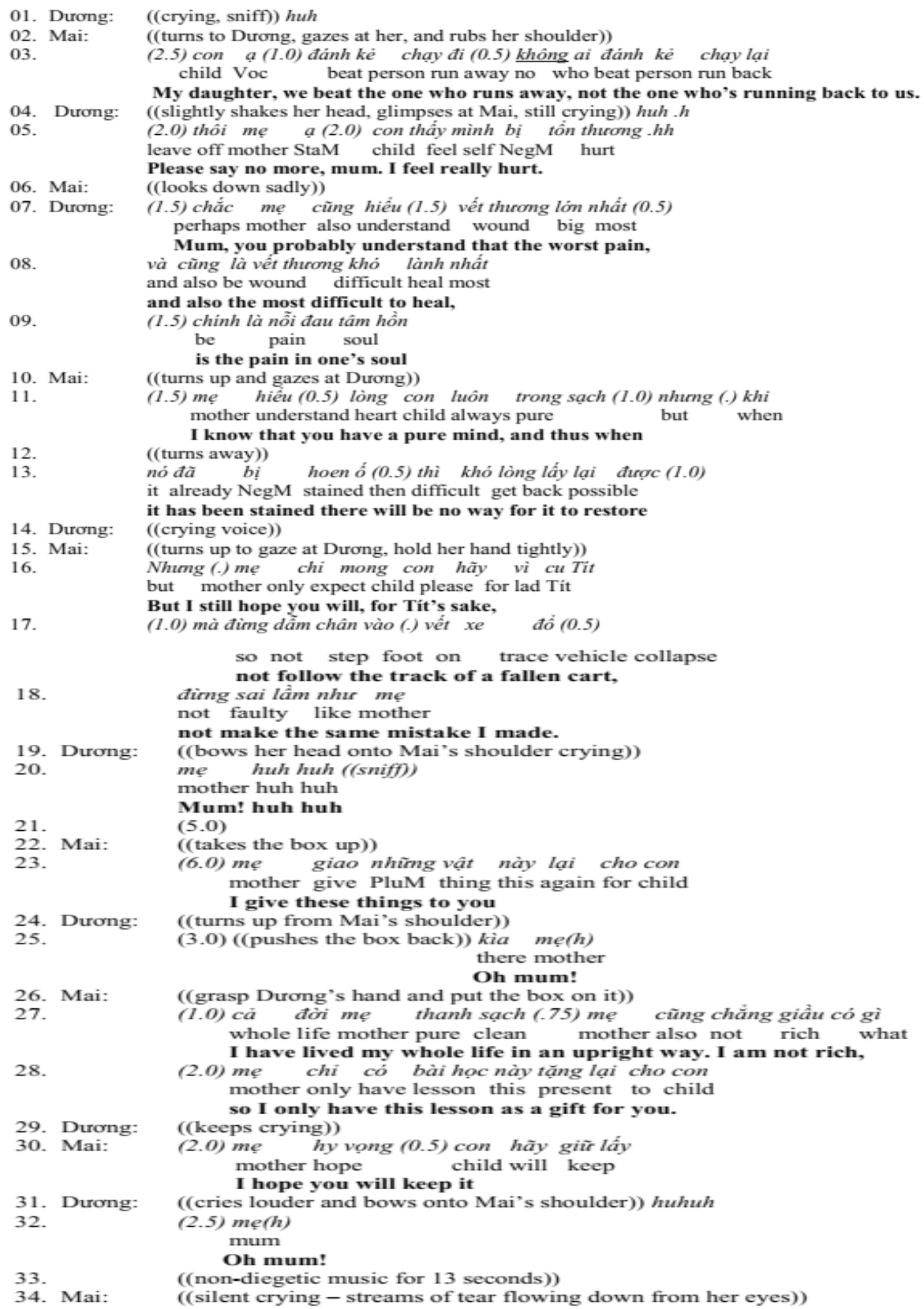

It can be seen that there are three adjacency pairs of advice - refusal in this excerpt. The first pair is from line 1 to line 9, the second from line 10 to line 21, and the third from line 22 to the end. The analysis below makes clear how each refusal in each pair is made.

3.1.2. The first refusal: language is accompanied by a number of paralinguistic and non-linguistic modes
After telling the story as a pre-advice, Mai decides to give her first piece of advice in line 3 using the proverb đánh kẻ chạy đi không ai đánh kẻ chay lại (lit. to beat the person who runs away and not to beat the person who runs back). This advice is made at the point of time when Mai recognizes that Dương has been involved in the story she has been telling with sufficient understanding. It is evidenced by the fact that Dương has shown she knows 
the story very well, and takes part in the story telling by mentioning the birth of her younger brother - Hoàng - and the bigger difficulties they experienced after Hoàng was born. Dương's full involvement in the story is also realized by her sad mood (sympathetic gaze and crying - lines 1, 4). This involvement projects Mai to transit from giving a pre-advice turn to making the actual advice. The vocative form con a (line 3) marks this transition and the accompanying proverb functions as an indirect advice.

In the Vietnamese culture, 'the person who runs away' denotes the one who commits a fault, but does not admit his or her wrongdoing. On the other hand, 'the person who runs back' refers to the one who recognises his or her fault and feels regretful and repentant about it. The verb 'beat' metaphorically means to punish somebody who commits a wrongdoing, and hence 'not to beat' means to forgive him or her. The proverb, therefore, teaches people to forgive those who have already recognized their wrongdoing and want to correct it. In saying this, Mai indirectly advises Dương to forgive her husband because he, as far as Mai could observe, has shown that he feels regretful about his infidelity.

Upon hearing the advice, Dương concurrently conducted a number of actions: she slightly shakes her head, glimpses at her mother and then looking down, keeps crying (line 4), and making a request back to her mother that she does not need to advise her (line 5) because she really feels hurt. Dương draws on all these modes to refuse her mother's advice and this shows the complexity of modes of communication in which the linguistic form (i.e the utterance of the request back) is only one. All these actions make Mai look down and away from Dương sadly (line 6). This reveals that she perceives Dương's verbal and non-verbal actions as the constitution of a refusal.

Then Dương gives further explanation (lines 7, 8, and 9) in a mitigating way: she says chắc me cũng hiểu (you probably understand, line 7) to seek her mother's sympathy. Seeking sympathy from Mai reveals Dương, too, is performing a perfect recipient design because she knows that she and her mother have "the existing mutual knowledge" (Hutchby \& Wooffitt, 2008, p. 130) about how a woman feels when she is betrayed by her husband. Apart from the fact that every woman would feel badly hurt if her husband was unfaithful, Mai knows exactly what the hurt feels like because she herself was betrayed by her husband a long time ago (as she reveals in her story). Therefore, by seeking her mother's sympathy Dương can make her reason for not forgiving her husband more convincing and hence her refusal stronger. If in the story Mai draws on the fact that getting divorce can make a woman's life really difficult in order to advise Dương, Dương draws on another aspect of the story, i.e., the serious hurt a woman would get from being betrayed by her husband, which Mai has been suffering, to refuse Mai's advice.

Through the analysis of this first adjency pair, we can see that Dương draws on a number of modes to refuse her mother's advice. She uses language (by making a request back to her mother and explaining the reasons) together with a number of other non-linguistic forms including gazing, shaking head, crying, among others. These modes are concurrently utilized and they together make her refusing more gentle on the one hand but more determining on the other.

\subsubsection{The second refusal: linguistic mode} becomes less prominent than non-linguistic ones

Upon interpreting Dương's verbal turns (lines 4-9) and non-verbal behaviour as a refusal, Mai continues to give the second advice by outlining another reason - vì cu Tít (for Tít's sake, line 16) - to explain why Dương should not consider getting a divorce. In this second attempt (lines 16-18) Mai intensifies her advice with a number of other non-linguistic actions: She turns to Dương again, grasps her hand, holds it tightly, gazes at her, and then pleads to her. Mai advises Dương to reconsider her decision to divorce her husband for the sake of 
the happiness of her son. It is widely observed that children are seriously influenced when parents decide to separate. Thus in reality, many couples choose not to divorce for the sake of their children. Through this further negotiation Mai is highlighting to Dương the responsibility she has for the happiness of her son. Moreover, by so doing Mai thinks she is providing Dương with a more convincing reason to reconsider her decision to get divorced. However, Dương again refuses, this time by bowing her head onto Mai's shoulder and crying louder (lines 19), and uttering only one word me (mum!) (line 20) before keeping a 5 -second silence (line 21).

The utterance of only one word me reveals that language has become less prominent than it is in Dương's first refusal. At this moment she relies more on non-linguistic modes (bowing her head onto her mother's shoulder, crying, and keeping silence), and thus these modes become embodied in this turn.

Although the utterance me does not itself constitue a refusal, it does when accompanied by those non-linguistic modes. And Mai interprets this series of action as Dương's refusal mainly because of her non-linguistic actions (e.g. crying and keeping silent). That is why Mai goes further in her attempt to advise Dương in her next turns.

\subsubsection{The third refusal: crying takes a} central role

The third adjacency advice-refusal pair starts when Mai picks up the box (line 22) used to store the bracelet, photos, and some letters. She decides to give those things to Dương with the hope that they will remind Dương of her own sad story and thus help her to change her mind. At first, Dương does not want to receive them, as evidenced by her pushing the box back (line 25). Because Mai insists, however, by grasping Dương's hand and putting the box in it (line 26), Dương has to receive it reluctantly. Mai's action of giving the box, together with her words (lines 23-30), reveals that she is very insistent on advising Dương to forgive her husband. What happens in the conversation shows that Mai may have prepared to give it to Dương before the conversation starts; and if so, she must have known in advance that advising her daughter is not easy and that her advice is very likely to be refused. It is because if Dương explicitly accepts her advice right at the beginning, she may not have to give it to her. Therefore, the fact that Dương does not explicitly accept is understood by Mai as an indirect refusal, and she also interprets Dương's later actions (crying on her shoulder [line 31] and repeating the exclamation me [line 32]) as another refusal. Thus, she keeps advising and requesting Dương in later conversations.

\subsection{The last conversation: Episode 32 (26'05- 28'30)}

Before the last conversation takes place, there have been other interactions between Dương and her family members. The second conversation (episode 22: 48'52-51'31) is between her and Mai in which Mai continues to request her to forgive her husband. The situational setting of this interaction is in front of the altar. In this conversation, Mai draws on a superstitious reason to make her request: she blames herself for not having been worshipping the ancestors and the deities properly, and so they punish them by controlling her daughter's thoughts, the result of which is that her daughter decided to get divorced. Therefore, in this interaction, she has to pray for their mercy, then she requests Dương to cancel her decision.

The third conversation (episode 25: 4'005 '44) takes place in a family meeting attended by all the family members (except Dương's son). This time, Mai decides to bring the issue on board as a family problem and makes an official direct request to Dương and Kinh to forgive each other. Once more, Dương refuses. The fourth conversation (episode 31: 54'2756 '14) is a special one because it is the dialogue in Dương's dream between her and her mother's 
ghost after the mother dies from an accident. In the conversation, the ghost (i.e. Dương's mother) advises Dương again to cancel divorcing and the reason she gives this time is that a lonely woman would become rigid and dry. The mother's death has had a great influence on Dương's attitude which is revealed in the last conversation analyzed below.

The excerpt below is the final part of the conversation between Dương and her husband. In this excerpt Kỉnh is trying to beg for Dương's forgiveness.

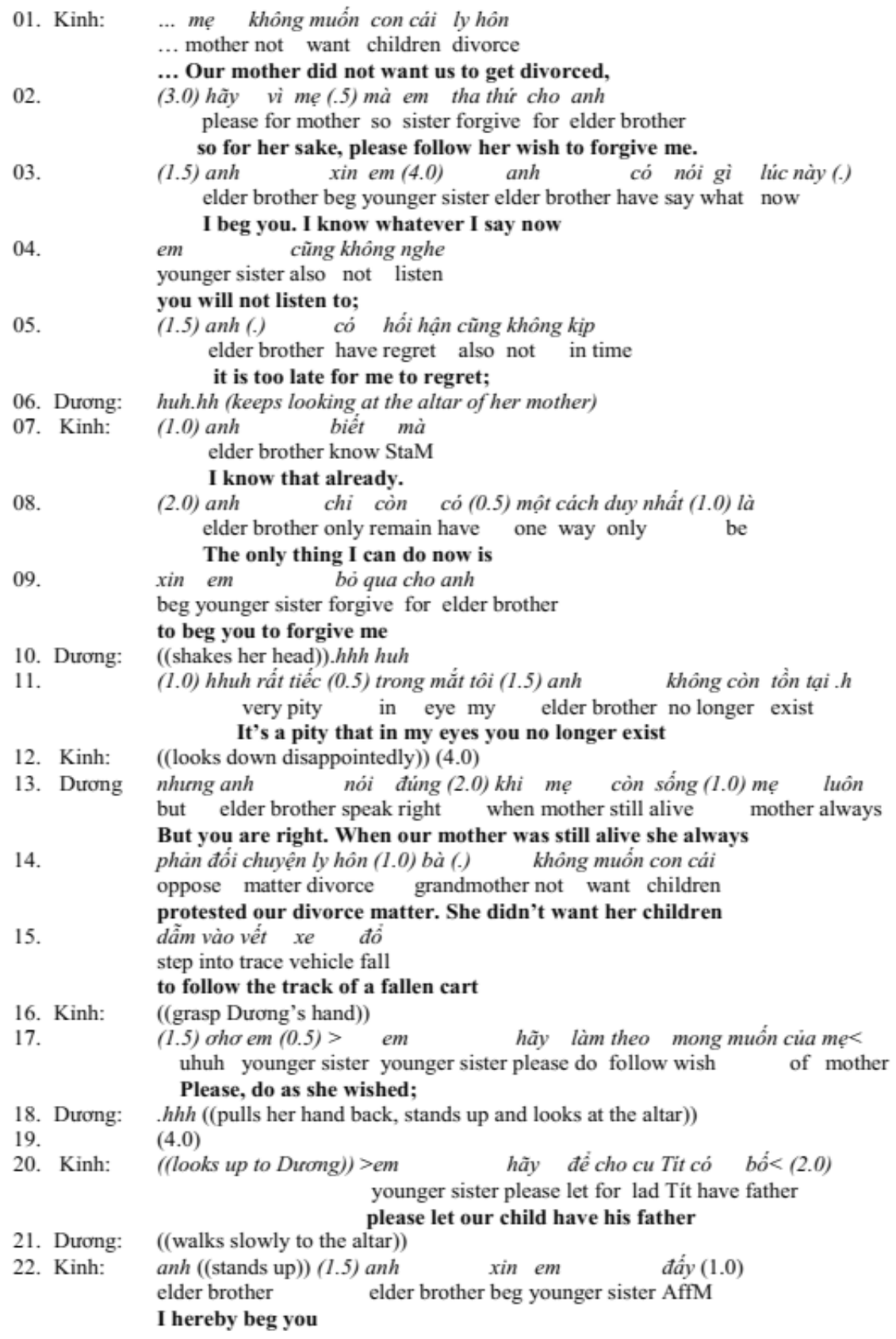




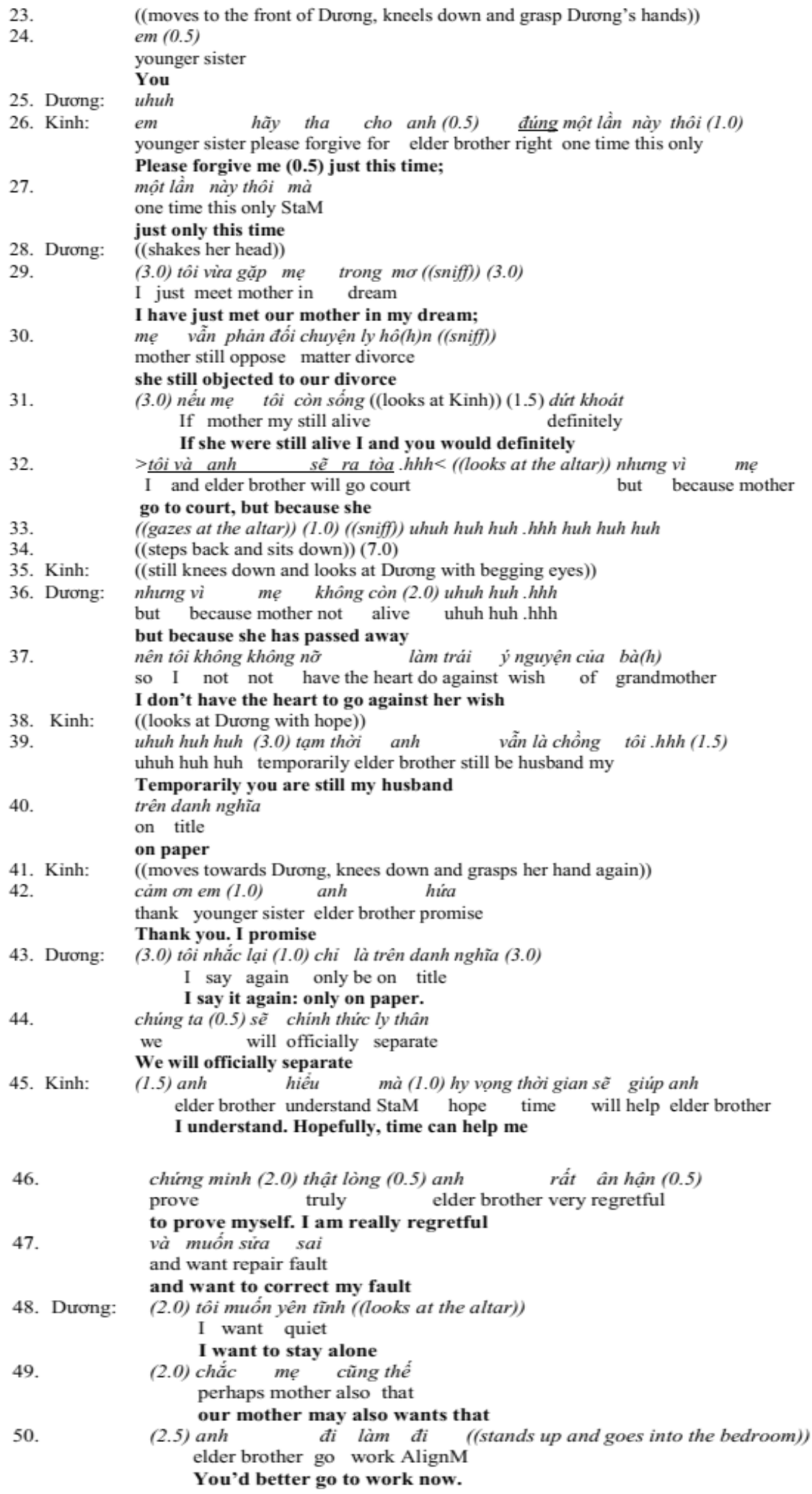


The excerpt can be divided into two parts. The first part is from the beginning to line 12 in which different non-linguistic actions are performed by Dương to refuse her husband. The second part is the remaining one and it marks the change in Dương's mind: she decides to forgive him. In each part, there are smaller adjacency pairs of request and refusal.

3.2.1. Refusing by ignoring, keeping silence, and shaking head

In this excerpt, Kỉnh begs Dương to accept her mother's advice to forgive him. He knows that Dương loves her mother very much and so she would accept her mother's advice. He mentions the fact that their mother did not want them to get divorced (line 1) as a pre-request with the hope that Dương will accept the mother's advice. However, she keeps silent for 3 seconds (lie 3), which is understood by him as a refusal to his prerequest, and this projects him to make the actual request by asking her to forgive him for the mother's sake (line 2). Again, what he receives is another silence of 1.5 second (line 3), which leads him again to make a real begging "I beg you" (line 3 ), and an even longer silence (4 seconds) is delivered. Thus, in this short moment, he has made several requests (including pre-request and begging) and receives several non-linguistic refusals in the form of silence. Dương does not bother to take her turn at the points where Kinh expects they are the transition relevance places (Sacks, Schegloff, \& Jefferson, 1974). It proves that Dương is trying to make Kinh understand that begging her to forgive him is not that easy and simple even though she may follow her mother's advice, which means she may forgive him.

During the interaction, although Dương is sitting opposite Kinh, she does not look at him but keeps gazing at the altar (line 6) where her mother is worshipped. This ignorance reveals that she hates him and sends him a message that she will not forgive him at this moment (although by looking at the altar, she implies that she might follow her mother's advice). Kinh may have realized that there is still some hope, so although interpreting Dương's ignorance as another refusal, he makes another attempt by repeating the begging (line 9); and only after Dương shakes her head and keeps crying (line 10), and states that he does not exist in her eyes (line 11) does he know that all his effort to persuade her cannot succeed. His action of looking down disappointedly (line 12) proves that he has perceived all the actions made by Dương as the performance of a refusal.

In this part, Kinh admits that his fault is so serious that Dương will not accept any excuse; but he is smart in that he draws on the fact that her mother wanted her to forgive him as the reason she will be most likely to consider. As such, he touches upon Dương's weakest point in her psychological state; that is, she loves her mother very much and thus she will be very likely to follow her mother's advice even though she does not want to forgive him. Therefore, he is putting Dương in the context that her forgiveness will be due to her mother's sake, not to his regretful behaviour. As such, he gives her the sense that she could forgive him but could still maintain her self-esteem that may be lost if she does so.

It can be stated that not until the turn in line 10 do non-linguistic forms, including keeping silent, looking at the altar, shaking head, crying etc, become embodied (Norris, 2004) because they are the main modes of communication that convey the message of a refusal. Language only takes its role in line 11 where Dương's utterance functions as a final refusal in the series of refusals made by keeping silence. 


\subsubsection{From refusing to accepting}

The conversation would end with a refusal by Dương if she did not continue her turn. After a pause for 4 seconds (line 12), which makes Kinh think she is refusing, she continues her turn with the word 'but' in line 13. This word is noticeable here because it introduces a big change in her attitude. By acknowledging that her mother did not want her to get divorced (lines 13-15), she goes back to the point Kinh made earlier in line 2 in which he begs her to forgive him for the mother's sake. This acknowledgement gives him a new hope because it may mean to him that she will follow her mother's advice as well as her request to forgive him.

Seeing that Dương seems to be convinced by that reason (i.e., for the mother's sake), Kinh takes this opportunity to make another request, this time with higher verbal density and a complexity of actions (Norris, 2004, 2009). The verbal density is realised in the different reasons he produces to ask for Dương's forgiveness. The first reason is the one he has made earlier, that is, to follow the mother's wish (line 17). The second reason is to let their son have his father (line 20). He makes these two sentences with fast speed (marked by the signs $>$ and $<$ on lines 17 and 20), which contributes to the urgency of his begging. Until this moment, Dương still seems to be reluctant to accept: when he grasps her hand (line 16), she pulls it back in a forceful manner (line 18), then she stands up (line 18), keeps looking at the altar, and then walks towards the altar (line 21). Normally, these non-verbal actions would be interpreted as a refusal, but in this interaction, they are performed after she has given him a hope as analysed in the paragraph above, and thus they would be regarded not as a real refusal but as a challenge she wants to give him. In other words, with these actions she may want to transmit to him a message that "you made a really serious mistake that hurts me a lot, and so I will not forgive you easily unless you beg me more". In fact, Kỉnh perceives Dương's actions in that way, so he continues to convince her by a complexity of other actions, verbal and non-verbal. He speaks faster, begs her - 'I hereby beg you' (line 22), stands up and moves to her front (lines 22, 23), kneels down in front of her and grasps her hand (line 23), and gives a heavy stress on the word dung in the phrase đúng mọt lần này thôi (line 26).

Again, Dương shakes her head (line 28) but it does not seem to be a refusal because after 3 seconds she returns to talk about her dream of meeting her mother (line 29) and informs him that her mother still resists her decision to get divorced (line 30), which she has already mentioned in lines 13, 14). This information together with the head shake can be interpreted as "I will not accept your begging, but I will rethink of my mother's wish", and they give Kinh a new hope that she will declare her forgiveness. However, she does not explicitly say that she will forgive him as a responsibility she would take to obey her mother. Until this point, what she says is just a conditional sentence (lines 31, 32): if her mother were still alive, she and he would definitely get divorced. This utterance implies that she might forgive him because her mother has died, and Kinh should interpret it that way. However, he keeps kneeling in front of her (line 35) as if his fault has not been relented. Even after Dương says that because her mother has passed away, she will not go against her wish (line 36, 37), he still feels uncertain; so he looks at Dương with some hope (line 38). His actions at this moment reveal that he must have thought that his fault is so serious that his wife will not forgive him easily, and thus he is expecting an explicit 
statement of tolerance from her. Therefore, only after she clearly declares that he is still her husband, on paper, (lines 39, 40) does he express his thanks and gratitude.

It is noticeable here that Dương only fulfills her responsibility in order to satisfy her mother after she has passed away, and if her mother was still alive, she would not do so (lines 31 , 32). This conditional shows that the Confucian teaching of women's reponsibility to do what their parents want has strongly imprinted on Vietnamese women's mind to the extent that they tend to do something as a priviledge for their deceased parents which they would not do if their parents were still alive.

Therefore, before the conversation takes place, Dương must have prepared to reconsider her decision to divorce Kinh after her mother died although she does not let him know her true intention at the beginning of the conversation. This is revealed by the fact that she keeps looking at the altar when talking to him, and keeps refusing him.

It can be seen from this analysis that Dương's actions of refusing and then accepting her husband's begging are performed by many means of communication apart from language. All the actions of crying, looking at the altar, bowing slightly forward and staring at her husband while he is still kneeling on the floor, and gazing angrily at him play a very important role in conveying the message and expressing her attitude.

\section{Conclusion}

The analysis of the two filmic excerpts has answered the two main research questions and one conclusive one as follows.

4.1. Refusing and related speech acts are mediated by different modes of communication
Drawing on CA and MIA, this paper demonstrated that refusing and related speech acts such as advising, requesting, and begging are often performed via a number of communication modes. Language is an important means of communication, but not the only one. It can play a major role at certain moments, but minor role at other times. As documented throughout this paper, modes other than language such as gazing, maintaining silence, crying and so on become embodied (Norris, 2004) in different stages of an interaction.

Material objects, often referred to as disembodied modes of communication (Norris, 2004), can also play a very important role in conveying the intended message. In the first conversation, for example, the bracelet, the photos, and the letters are used by the mother because she thinks that those things will remind Dương of the sad story of the mother's divorce which has caused a lot of difficulties to her. In the last conversation, the altar used to worship the spirit of her mother also reminds her of the responsibility she must take (i.e., to obey her mother). For this reason, when Dương is talking to Kinh during this conversation she always faces and gazes at the altar as if she is talking to her mother, who is already dead. It is therefore reasonable to state that not only linguistic, paralinguistic and non-linguistic modes can convey meaning, but material objects can also take certain roles. Very often, these modes are used concurrently with different degrees of complexity and intensity (Norris, 2004).

\subsection{Refusing is a process of negotiation}

Through the analysis of the divorce story a vivid picture was provided of how Vietnamese people refuse an advice or a request related to a high-stakes (i.e. potentially changes one's life) issue. Due to the high degree of face threat, refusing 
may occur several times in one interaction; for example, in the first conversation, there are three adjacency pairs of advice-refusal. Similary, in the last conversation, although Dương has already decided, right at the beginning of the conversation, to cancel her decision of getting divorced (evidenced in the fact that she keeps looking at the altar as if she is talking to her mother's spirit, which implies that she will accept her mother's requests that were made in previous conversations), she still makes a number of refusals by ignoring, maintaining silence, crying, and producing some utterances. Thus, these refusals can be understood as being made by Dương to signal her husband, Kinh, that she will not forgive him easily and that in order to be forgiven, he must show his really regretful behaviour.

Refusing also takes place through a long negotiation which is manifested in the five conversations in this story. Dương is very consistent at first, but since her mother does not give up advising and requesting her, she gradually changes her attitude. After a long period of negotiation, especially after her mother's death, she has become persuaded by the responsibility she has to fulfill to satisfy her mother and to please her mother's soul. As such, it can be concluded that refusals are both context-shaped and context-renewing (Heritage, 1984); that is, they are shaped by previous turns and they shape subsequent turns. It is demonstrated in the analyses of the conversations that how a refusal is made depends much on how the advice or the request is given; and how the refusal is made gives clues to how further advice or request is performed. To a larger extent, refusals are shaped by the previous conversation and shape the subsequent one. Thus, all the five conversations are linked together and constitute a coherent story containing the speech act of refusing.
4.3. Children's responsibility to obey their parents is still observed in the modern Vietnamese families

The analysis of this specific story of getting divorced reveals that a daughter's responsibility to obey her parents, one practice of filial piety, greatly influences her refusing. The fact that although Dương is very firm and consistent at first, her mother's death makes her change her decision in the last conversation proves this conclusion. That she finally takes her mother's advice to cancel her decision of getting divorced is the duty that she thinks she must do for her mother.

Although recent studies show that filial piety in the era of industrialization and globalization has become less strict than before, and children now often feel a burden to take care of their parents (Cao Thị Hải Bắc, 2018), the analysis of the interactional data in this paper explicates the fact that women's responsibility to obey their parents is still practised in Vietnam's contemporary society. However, the author does not conclude that this finding is contradictory to the trend found out in those studies. What this paper can contribute to the literature is that the finding is consonant with the view he mentions earlier that culture should be seen as very varied and even contested rather than stable and homogeneous.

In short, this paper does not aim to generalise the findings to a larger population; instead it tries to give a deep analysis of a specific case of getting divorce, which happens in a quite high percentage in contemporary Vietnam. From this analysis, we can see a relatively full picture of the impact of culture in everyday interaction. Nguyễn Hoà (2018) states that there is a dialectical relation between cultural values and the use of language, and that it is important for learners of a language 
to understand the underpinning culture. Since the findings of this paper show that refusing is not only manifested by language but also by non-linguistic forms, the author wants to broaden his view in that culture not only affects what people say but also what they do to convey what they want to say.

\subsection{Implications}

Although CA has been used quite widely in the world, it does not seem to be of great interest to Vietnamese researchers. In fact, there are few studies conducted by Vietnamese researchers drawing on CA to analyse speech acts in English and Vietnamese language. Similarly, MIA also receives the same stance in Vietnam.

It is therefore hoped that the findings presented in this paper will have some contribution to the literature of sociolinguistic research. In particular, it is expected that researchers in the field of pragmatics, especially master and $\mathrm{PhD}$ students who are going to apply CA and MIA in their research, will be able to find in this paper some new ideas for their selection of research topics. For example, they can select some types of conversations from some TV programmes such as conversations in some game shows. They may also be able to analyse comments taken from some social networks such as Facebook, Zalo, or Viber, or some interactions which are available on Youtube.com.

\section{References}

\section{Vietnamese}

Cao Thị Hải Bắc (2018). Biến đổi nhận thức về đạo hiếu: Nghiên cứu so sánh giữa Việt Nam và Hàn Quốc. Nghiên cứu Nước ngoài, 34(3), 11-23.

Nguyễn Phương Chi (1997). Từ chối - một hành vi ngôn ngữ tế nhị. Ngôn ngũ \& Đời sống, 25(11), 12-13.
Nguyễn Phương Chi (2004a). Một số chiến lược từ chối thường dùng trong tiếng Việt. Ngôn ngũ, 3, 22-29.

Nguyễn Phương Chi (2004b). Một số đặc điểm ngôn ngũ - văn hóa ứng xử của hành vi tù chối trong tiếng Việt - Có sư đối chiếu với tiếng Anh (Luận án tiến sỹ). Viện Khoa học Xã hội Việt Nam.

Vũ Tiến Dũng, Nguyễn Thị Thu Thuỷ (2009). Một số chiến lược từ chối lịch sự lời mời trong giao tiếp. Ngũ học toàn quốc 2009, 57-61.

Nguyễn Hoà (2018). Giá trị văn hoá: Một số hàm ý cho nghiên cứu ngôn ngữ trên cơ sở giá trị văn hoá và giao tiếp liên văn hoá. Nghiên cưu Nước ngoài, 34(1), 1-15.

Lưu Quý Khương, Trần Thị Phương Thảo (2008). Nghi thức lời từ chối một đề nghị giúp đỡ trên cơ sở lý thuyết hành vi ngôn ngữ (tiếng Anh so sánh với tiếng Việt). Ngôn ngũ, 2, 13-21.

Trần Chi Mai (2005a). Cách biểu hiện hành vi từ chối lời cầu khiến bằng các phát ngôn lảng tránh (trên cứ liệu tiếng Anh và tiếng Việt). Ngôn ngũu, 1, 41-50.

Trần Chi Mai (2005b). Lời từ chối gián tiếp với đặc trưng tư duy văn hoá dân tộc. Ngôn ngũ \& Đời sống, $113(3), 6-8$.

Trần Chi Mai (2005c). Phuoong thức biểu hiện hành vi tù chối lời cầu khiến trong tiếng Anh - Liên hệ với tiếng Việt (Luận án tiến sỹ). Trường Đại học Khoa học Xã hội và Nhân văn - Đại học Quốc gia Hà Nội.

Trần Chi Mai (2005d). Từ chối - chấp nhận và chấp nhận - từ chối. Ngôn ngũu \& Đời sống, $111+112(1+2)$, 51-55.

\section{English}

Al-Eryani, A. A. (2007). Refusal Strategies by Yemeni EFL Learners. The Asian EFL Journal Quarterly, 9(2), 19-34.

Allami, H., \& Naeimi, A. (2011). A cross-linguistic study of refusals: An analysis of pragmatic competence development in Iranian EFL learners. Journal of Pragmatics, 43, 385-406.

Beebe, L. M., \& Cummings, M. C. (1996). Natural speech act data versus written questionnaire data: How data collection method affects speech act performance. In S. M. Grass \& J. Neu (Eds.), Speech acts across culture. Berlin: Mouton de Gruyter.

Beebe, L. M., Takahashi, T., \& Uliss-Weltz, R. (1990). Pragmatic Transfer in ESL Refusals. In R. C. Scarcella, E. S. Andersen, \& S. D. Krashen (Eds.), Developing communicative competence in a second language. New York: NewBurry House Publishers.

Blum-Kulka, S. (1982). Learning to Say What You Mean in a Second Language: A Study of the Speech Act Performance of Learners of Hebrew as a Second Language. Applied Linguistics, 3(1), 29-50. 
Bowles, H. (2009). Storytelling as interaction in "The Homecoming". Language and Literature, 18(1), 45-60.

Bowles, H. (2011). The contribution of CA to the study of literary dialogue. Novitas-ROYAL (Research on Youth and Language), 5(1), 161-168.

Félix-Brasdefer, C. (2006). Linguistic politeness in Mexico: Refusal strategies among male speakers of Mexican Spanish. Journal of Pragmatics, 38(12), 2158-2187.

Félix-Brasdefer, C. (2008). Politeness in Mexico and the United States: A contrasty study of the realization and perception of refusals. Amsterdam: John Benjamins.

Garfinkel, H. (1967). Studies in Ethnomethodology. Englewood Cliffs: Prentice Hall.

Goffman, E. (1983). The Interactional order. American Sociological Review, 48(1), 1-17.

Herman, V. (1998). Turn management in drama. In J. Culpeper, M. Short, \& P. Verdonk (Eds.), Exploring the Language of Drama (pp. 19-33). London: Routledge.

Hutchby, I., \& Wooffitt, R. (2008). Conversation analysis: Principles, practices and applications (2nd ed.). Cambridge: Polity Press.

Gumperz, J. J. (1982). Discourse strategies: Studies in interactional sociolinguistics. Cambridge: Cambridge University Press.

Ivanchenko, I. (2007). An “interactive" approach to interpreting overlapping dialogue in Caryl Churchill's "Top Girls" (Act 1). Language and Literature, 16(1), 74-89.

Jefferson, G. (2004). Glossary of transcript symbols with an introduction. In G. H. Lerner (Ed.), Conversation analysis: Studies from the first generation (pp. 1331). Amsterdam: John Benjamins.

Kasper, G., \& Dahl, M. (1991). Research methods in interlanguage pragmatics. Studies in Second Language Acqusition, 13, 215-247.

Kwon. (2004). Expressing refusals in Korean and in American English. Multilingua, 23, 339-364.

Leech, G. (1983 ). Principles of Pragmatics. London: Longman.

Matsumoto, D., \& Juang, L. (2004). Culture and psychology (3rd ed.). Belmont: Wadsworth.

Mills, S., \& Kádár, D. Z. (2011). Politeness and culture. In D. Z. Kádár \& S. Mills (Eds.), Politeness in East Asia. Cambridge: Cambridge University Press.

Mortensen, K. (2013). Conversation Analysis and Multimodality. In A. C. Carol (Ed.), The Encyclopedia of Applied Linguistics. Hoboken: Blackwell Publishing Ltd.

Nguyen Thi Hanh \& Ishitobi, N. (2012). Ordering fastfood: Service encounters in real-life interaction and in textbook dialogs. Japan Association for Language Teaching Journal, 34(2), 151-185.

Nguyen Thi Thuy Minh (2011). Learning to communicate in a globalized world: To what extent do school textbooks facilitate the development of intercultural pragmatic competence? RELC Journal, 42, 17-30.

Nguyễn Thị Minh Phương (2006). Cross-cultural pragmatics: Refusals of requests by Australian native speakers of English and Vietnamese learners of English. (MA Thesis), University of Queensland.

Nguyễn Trọng Du (2016). The Culture of Vietnamese refusing: A mixed-methods multiperspectival approach (Unpublished $\mathrm{PhD}$ dissertation). Macquarie University, Australia.

Norris, S. (2004). Analyzing multimodal interaction: A methodological framework. New York \& London: Routledge.

Norris, S. (2009). Modal density and modal configurations: Multimodal actions. In C. Jewitt (Ed.), The Routledge handbook of multimodal analysis. London: Routledge.

Parvaresh, V., \& Tavakoli, M. (2009). Discourse completion tasks as elicitation tools: How convergent are they? The Social Sciences, 4(4), 366-373.

Phan Thị Vân Quyên (2001). Some English-Vietnamese cross-cultural differences in refusing a request (MA Thesis). University of Languages and International Studies - Vietnam National University, Hanoi.

Pike, K. L. (1954). Language in relation to a unified theory of the structure of human behaviour. The Hague: Mouton.

Sacks, H. (1992a). Lectures on conversation (Vol. 2). Oxford: Basil Blackwell.

Sacks, H. (1992b). Lectures on conversation (Vol. 1). Oxford: Basil Blackwell.

Sacks, H., Schegloff, E. A., \& Jefferson, G. (1974). A simplest systematics for the organization of turntaking for conversation. Language, 50(4), 696-735.

Sbisà, M., \& Turner, K. (Eds.) (2013). Pragmatics of speech actions (Vol. 2). Berlin/Boston: Walter de Gruyter.

Scollon, R. (2001). Mediated discourse: The nexus of practice. London/New York: Routledge.

Scollon, R., \& Scollon, S. W. (2009). Multimodality and language: A retrospective and prospective view. In C. Jewitt (Ed.), The Routledge handbook of multimodal analysis. London: Routledge.

Thomas, J. (1983). Cross-cultural pragmatic failure. Applied Linguistics, 4(2), 91-112.

Triandis, H. C. (1994). Culture and social behavior. New York: McGraw Hill. 


\title{
"NẾU ME TÔI CÒN SỐNG, TÔI VÀ ANH SẼ RA TÒA": MỘT NGHIÊN CỨU TRƯỜNG HỢP VỀ LỜI TỬ CHỐI CỦA PHỤ NƯ VIỆT NAM
}

\author{
Nguyễn Trọng Du \\ Khoa Ngoại ngũu, Đại học Thái Nguyên, Quyết Thắng, Thái Nguyên, Việt Nam
}

Tóm tắt: Bài báo giới thiệu những kết quả chính của một nghiên cứu gần đây được thực hiện nhằm tìm hiểu xem người phụ nữ Việt Nam từ chối một lời khuyên hay lời yêu cầu liên quan đến việc hệ trọng như thế nào trong những tương tác hàng ngày. Dữ liệu được sử dụng để phân tích trong nghiên cứu này là các đoạn thoại trích từ bộ phim dài tập có tựa đề Nhũng công dân tập thể. Công cụ phân tích dữ liệu được sử dụng là sự kết hợp giữa Phân tích hội thoại (Conversation Analysis) và Phân tích Tương tác Đa phương tiện (Multimodal Interactional Analysis). Kết quả nghiên cứu cho thấy (1) hành động từ chối của người Việt thường được thực hiện cùng một lúc bởi nhiều phương tiện giao tiếp khác nhau trong đó ngôn ngữ chỉ là một phương tiện; (2) hành động từ chối một lời khuyên hay lời yêu cầu liên quan đến việc hệ trọng thường mất nhiều thời gian thương lượng trong một hay nhiều cuộc thoại; (3) trách nhiệm vâng lời cha mẹ của phụ nữ Việt Nam, một giá trị Nho giáo, vẫn có vai trò nhất định trong xã hội hiện đại.

Tù khoá: hành động từ chối của người Việt, lời từ chối, dữ liệu tương tác, phân tích hội thoại, phân tích tương tác đa phương tiện

\section{APPENDIX}

\section{Transcription conventions}

[ Left square bracket: a point of overlap onset

$=\quad$ Equal signs: 1. Two lines are connected; 2. One turn is latched by another

(0.5) Numbers in parentheses: silence, represented in tenths of a second

(.) A dot in parentheses: a micro-pause (usually less than $0.2 \mathrm{~s}$ )

$:$ Collons: prolongation or stretching of the sound

Word Underlining: stress or emphasis by increased loudness or higher pitch

WORD All capital letters: much louder than the surrounding words

$><\quad$ More than, less than: with a jump-start, said in rush quickly

hhh Out-breath

.hhh In-breath

(( )) Double parentheses: transcriber's comments

\section{Abbreviations}

Voc Vocative

PluM Plural marker

NegM Negative marker

AffM Affirmative marker

StaM Stance marker

AlignM Alignment marker 